\title{
Email communication and language learning - an Australian case study
}

\author{
Matthew Absalom \\ University of South Australia, Australia \\ Mariolina Pais Marden \\ University of Wollongong, Australia
}

We discuss the ramifications the use of email communication can have for teaching and learning languages.

\section{INTRODUCTION}

The aim of the present study is to offer a reflection on the specific traits of text-based computer-mediated communication (CMC) (in this case, email) in the context of foreign language learning in order to further the discussion of both its pedagogical implications and of online language learner behaviour, an area as yet not fully explored (Roed, 2003, p. 157, n. 2). After a description of the rationale and context of the study, we focus on certain aspects of CMC. In particular we consider:

- the effects of email conversation on participation and engagement of the learners

- the effects of spatial, temporal and psychological distance on the type of communication produced in the electronic context;

- the hybrid nature of email messages which sit somewhere between written and spoken discourse;

- the relationship between form and content;

- the creativity in expression of the language produced.

Restrictions of space make it necessary to focus the discussion on these issues. Future work will explore other aspects such as the effect of the virtual presence of teaching staff, the role of prior linguistic knowledge and language learning experiences, and the relationship between NNS-NNS versus email communication between native speakers..

\section{RATIONALE}

One of the perennial difficulties for teachers of languages is how to encourage interaction successfully between learners in the target language. This is especially problematic in a context such as ours where the majority of learners all share a common language (English). The need to address the problem of limited oral interaction between students in language classes, most notable in the initial stages of all courses regardless of level, provided us with a motive for considering alternative means of communication. We opted for email for two reasons. First, in the current climate of technologisation of education, some form of text-based CMC seemed appropriate. Due to its ubiquity and general 
familiarity, we chose to incorporate the use of email into the teaching program across all levels of Italian. Second, since all students of Italian were to be involved, the asynchronous features of email, as opposed to either synchronous CMC or real-life meetings, were seen as more attractive.

Sproull \& Kiesler describe certain aspects of email communication which are highly relevant to a teaching and learning context which aims at fostering interaction. In their words,

Ordinarily when people communicate, they aren't just exchanging information, they are projecting an image of themselves. This knowledge can make them shy in front of others, especially those whose respect they most desire. Ephemerality and plain text in electronic mail reduce the fear of appearing foolish in front of others. By removing reminders of a possibly critical audience, electronic mail induces people to be more open. (Sproull \& Kiesler, 1991, p. 42)

They go on to raise a very important consideration relating to the social context of CMC, noting that "communication technologies weaken social differences apparent in face-toface communication" (Sproull \& Kiesler, 1991, p. 43). This social levelling is crucial in a teaching and learning context because interaction in language classes is often hampered by students' perceptions of their classmates: for example, "I can't possibly speak Italian in front of those people". Roed supports this position when she describes the electronic environment as one in which "there are no immediate [negative] reactions such as giggles or raised eyebrows" (Roed, 2003, p. 170).

Turning to the specific context of languages education, in the last ten years the use of email communication has been successfully integrated into the teaching of languages at university level (Warschauer \& Kern, 2000; Chapelle, 2001). This has profoundly altered the dynamics of interaction creating a learning environment which can be characterised as interactive and collaborative as well as student-centred (Warschauer, 1996; Spina, 1998; Porcelli \& Dolci, 1999; Leahy, 2001). Through the use of email communication, an increasing number of scholars argue that students can exercise and acquire the target language in an authentic, motivating environment which offers real communicative goals. (Beavois \& Eledge, 1995; Warschauer, 1996; Porcelli \& Dolci, 1999; Fedderholt, 2001). Shyness, embarrassment, difficulty or fear of expressing one's self - even in first language - represent considerable hurdles to successful language acquisition and use. Email or networked communication represents a means of interpersonal communication which, due to its physical and/or temporal characteristics can reduce these psychological barriers (Richards \& Rogers, 1986; Sullivan, 1998; Roed, 2003). Kitade (2000, p. 147) supports this position noting that quiet learners are more expressive in CMC contexts compared with face-to-face interaction and that the "absence of authority" in CMC facilitates equal interaction due to a lack of intimidating non-verbal cues. Stockwell (2003, p. 38) summarises a range of advantages associated with the use of email based on previous studies. These include increases in motivation due to interaction with a real audience, reduction in stress through anonymity, opportunities for authentic communication, increased participation and development of learner autonomy. It is also possible that students feel more comfortable interacting in CMC because there is no fear of bad pronunciation. A colleague and moderately successful language learner commented that, for her, text-based CMC would be an attractive mode of interaction 
precisely because no one can hear your errors of pronunciation and hesitations. Roed elaborates a similar position when she claims that "if...the language students emailed...their anxieties would immediately be reduced. Worries about peculiar accents their own or the person they are addressing - are no longer an issue, and they are not present when the recipient comments on the grammatical blunders" (Roed, 2003, p. 158). Our supposition that the quasi-universality of email made it a viable and technically simple choice was confirmed. Indeed, almost all the students who participated in our project were technically capable of and familiar with communicating using email.The technical characteristics of email render it very appealing in a teaching and learning context. Namely, email allows a person to reply directly to the sender while conserving the sender's entire original text. This facilitates dialogue in a way not dissimilar to conversation but with the advantage that each participant can decide independently on the pace and their own rhythm (Bertocchi 1999; Porcelli \& Dolci 1999). Furthermore, the various "turns" can be preserved in the email allowing learners to go back and review earlier messages, providing valuable stimulus for reflection. This is a distinct advantage over oral communication which is fleeting and is not generally preserved.

\section{RESEARCH QUESTIONS}

When we designed the email exchange exercise, we did not initially intend to treat it as a research exercise but rather as a moment of innovative teaching and learning. However, once we began collecting the exchanges for assessment purposes we realised that we had stumbled upon a rich source of "data" which led us to pose questions about the type of communication and language learning activities the students were undertaking. Unsolicited evaluative comments made by students signalled to us the value of the exercise and the importance of writing up our observations.

During the course of the exchanges, clear research questions began to emerge. In looking back at the various email conversations, we decided to explore the following points:

- how does email communication affect the participation and engagement of the learners?

- how does the asynchronous nature of email impact on communication?

- What are the effects of distance, both physical and psychological?

- Is email communication written or spoken language, or something entirely different?

- What is the relationship between the form and content of email messages?

- What type of language is produced?

All these questions lead inevitably to a consideration of the ramifications that the integration of text-based $\mathrm{CMC}$ has for the teaching and learning of languages.

\section{ETHICAL CONSIDERATIONS}

Once we realised that we would use the "data" in a research context, we sought the appropriate release to publish the exchanges from the students. We felt this was necessary because the students wrote about themselves to varying degrees in personal tones.

\section{CONTEXT}

The email exchange exercise consisted of two interactions of up to 5 dialogic exchanges. The first email exchange took place in weeks 4-6 of semester 1 . The second interaction was held in the last weeks of the semester. At ANU, there were two semesters of 11 weeks, with the academic year following the calendar year as is normally the case in Australian universities. 


\section{PARTICIPANTS}

The exchanges took place in semester 1 (March-July), 2000 and involved approximately 80 students across four levels (Introductory, Continuing, Intermediate, Advanced) in the Italian program at the ANU.

\section{PHASES}

The exercise consisted of three distinct phases.

1. Email exchange initiation

To initiate the email exchanges, a mailing list was created to which all students were subscribed by one of the instructors. Each student sent an introduction of themselves in Italian to the mailing list. These approximately 80 introductory emails arrived in the inbox of each participating student.

2. Choosing messages for the first email interaction

Students then chose the message/messages to answer and this gave rise to the first virtual dialogue with another student. This exchange took place between students via their institutional or personal email accounts, not through the mailing list.

3. Second email interaction

The second email interaction could either be a continuation of the earlier dialogue or a new virtual discussion with a different student. As a means of beginning a new dialogue, we suggested sending a review of a film/book/CD to the mailing list and then choosing the messages to answer as in the earlier dialogue.

\section{ASSESSMENT}

We decided to dedicate a percentage of the final mark for each level of Italian to the email exchange exercise both to motivate student participation and to ensure maximum participation in the email project. Here we invoke Ramsden's (1994:185) principle of using assessment to "encourage interest, commitment, and intellectual challenge". Each interaction was worth $5 \%$ of the overall mark to make up a total $10 \%$. In assessing the exchanges we wanted to emphasise communication and creativity in expression and avoid the perception that the email messages could be reduced to a simple exercise of grammar. Consequently, the exchanges were evaluated with reference to a set of four criteria which was communicated to the students at the start of the project. The criteria were: communication, clarity, cohesion and correctness. We weighted the first three criteria at $30 \%$, while the final one made up the remaining $10 \%$ of the first $5 \%$ of the overall mark. Communication, clarity and conhesion relate to the purely communicative aspects of the messages and what we were looking for in concrete terms were features such as:

- Messages which invited dialogue: not just simple statements but requests for information;

- Dialogues which demonstrated communication: clear questioning and answering; shared development of ideas;

- Topics which continued over the duration of the exchange.

Correctness referred specifically to issues such as morphological and orthographic accuracy and particularly in cases where communication was hampered.

Following the first series of email exchanges, it became clear that the four criteria were not sufficient to capture the differences in depth of content apparent across the exchanges. We therefore decided to add a fifth criterion: content. The percentages were subsequently reviewed and each of the five criteria was weighted equally at $20 \%$ of the 
second $5 \%$ of the overall mark. We took both a quantitative and a qualitative approach to assessing this fifth criteria in the sense that we opted to mark more favourably contributions which were both more sustained and wider-ranging in content. Typically, these more successful exchanges focused on personally developed topics not limited to textbook style exchanges, such as descriptions of age, family, university study, etc. We also considered it appropriate to increase the weighting of correctness from $10 \%$ to $20 \%$ of the overall mark in the second exchange given that by the time the students undertook the second exchange they had all practically completed at least one semester of formal study of Italian.

\section{DATA COLLECTION}

The textual nature of email communication greatly facilitated data collection. All the introductory emails sent to the mailing list were automatically forwarded to the teaching staff and subsequently saved. At the end of the semester, all project participants submitted their exchanges in electronic form. The exchanges were saved in chronological order, easily accessible and available for consultation at any moment, saving time and space.

\section{DISCUSSION}

In this section we discuss our findings in relation to the research questions posed at the beginning of the article. Where appropriate, we have included examples taken from the email exchanges. These are provided both in their original form (i.e. in Italian) and with English translation. In our translations we have not attempted to represent spelling infelicities, grammatical irregularities or other idiosyncracies. We do, however, highlight these when relevant to the discussion.

\section{PHYSICAL AND PSYCHOLOGICAL DISTANCE}

Baron (1984) notes that one of the most significant social effects of CMC is a higher degree of participation with respect to oral interaction. Furthermore, she observes that many students feel more comfortable with CMC than when communicating orally. Roed (2003), almost 20 years later, reaffirms this situation. The implications that this can have for languages education are obvious and notable in relation to the current study. In our case, email communication allowed some of the shyest students, who never would have initiated a communicative exchange spontaneously, the chance to interact in Italian without the fear of embarrassment in front of the whole class. It is worth noting than a number of the least outgoing students produced messages of considerable length and expressive creativity.

In her study of the language of electronic diaries of students of Spanish, Gonzales-Bueno (1998) highlights that the act of writing that occurs outside that class context - at home or in the language lab - creates a physical and psychological distance which can be beneficial in the way in which it leads to a wider variety of topics and linguistic structures.

Evidence of the perception of physical/psychological distance can be seen in the introductory messages of a number of mature age students which include a comment on their age as well as an explanation of their motivation for studying Italian:

\begin{tabular}{|l|l|}
\hline Mi chiamo D . Sono una & My name is D. I'm an \\
studente vecchia (!!) .... Non & old (!!) student...I'm not \\
studio per una laurea, imparo & studying for a degree, I'm only learning \\
l'italiano solo. Studio la lingua & Italian. I study the language \\
\hline
\end{tabular}




\begin{tabular}{|l|l|}
\hline perche mi piace la cultura e la & because I like the culture and \\
storia d'Italia. Vorrei andare & history of Italy. I'd like to go \\
in Italia per un periodo lungo e & to Italy for an extended period and \\
visitare le piccole citta, e la & visit the small cities, and the \\
campagna.... & country... \\
\hline Mi chiamo J. Dopo aver letto & My name is J. After reading the \\
altri messagi, vedo che non & other messages, I see that I'm not \\
sono la sola vecchia donna & the only old lady \\
all'università!! Coraggio alle & at uni. More power to the \\
altre !! Ho quaranta-qualcose anni..... & others!! I'm forty-something \\
Studio l'italiano & years old...I'm studying Italian \\
perche siamo andati in Italia & because we went to Italy \\
1995 e mi e molto piaciuto la & in 1995 and I really liked the \\
lingua, la cultura la gente. & language, the culture the people. \\
\hline Mi chiamo R le vieux perchè sono il più & My name is R le vieux because I'm the \\
vecchio studente d'italiano del mondo. & oldest student of Italian in the world. \\
Studio l'italiano perchè sono un po' & I'm studying Italian because I'm a bit \\
pazzo. Alla mia età è molto difficile. Ho & crazy. At my age it's very difficult. I've \\
già studiato il francese un po' e sto & already studied French a bit and I'm \\
studiando anche il latino. Voglio parlare & also studying Latin. I want to speak \\
l'italiano per cognoscere degli italiani e & Italian to get to know the Italians and \\
forse per viaggiare in Italia. Ma studio la & perhaps to travel in Italy. But I study the \\
lingua anche per scoprire la letteratura & language also to discover Italian literature. \\
italiana. Per me, la letteratura di un paese & For me, the literature of a country \\
è spesso una buona finestra attraverso la & is often a good window through \\
quale posso guardare una società & which I can observe a particular \\
particolare. & society. \\
\hline We can say that the electronic environment & \\
\hline
\end{tabular}

We can say that the electronic environment created the necessary distance for the students to feel free to proffer observations of a highly personal nature which they may not have expressed either in traditional writing exercises or conversation classes. These comments can be considered a positive outcome of the less anxiety-ridden atmosphere created by the electronic medium.

In relation to the physical distance noted above, it is possible to identify a series of metalinguistic traits which are not found in traditional class-based writing. The fact that the students could communicate when and where they preferred was reflected in the use of greetings and salutations which differ from those used in traditional written exercises

\begin{tabular}{|l|l|}
\hline $\begin{array}{l}\text { Finero' qui perche ho niente } \\
\text { dire, ed anche devo andare in biblioteca } \\
\text { studiare per gli esami }\end{array}$ & $\begin{array}{l}\text { I'll finish here because I have nothing to } \\
\text { say, and I have to also go to the library } \\
\text { to study for my exams }\end{array}$ \\
\hline ... ` tardi e ho sonno & it's late and I'm tired \\
\hline Vado - ho lezione in uno minuto! & I'm off - I've got a class in one minute! \\
\hline $\begin{array}{l}\text { Sono le nove di mattina e ho lezione di } \\
\text { storia l'arte fra poco! }\end{array}$ & $\begin{array}{l}\text { It's nine in the morning and I have an } \\
\text { art history lecture soon! }\end{array}$ \\
\hline
\end{tabular}

These expressions are very similar to comments one would find in the course of a typical telephone conversation - the writer feels the need to describe her personal situation to the interlocutor (Bertocchi, 1999) - it's as if the writer is speaking in real-time with their 
interlocutor. Indeed, Roed describes synchronous CMC as "a medium somewhere between a telephone conversation and a letter" (Roed, 2003, p. 169). We would make the same assertion for email communication. Furthermore, this style of communication underscores the success of email as a way of promoting dialogue.

It is also worth noting the frequent recourse to elements which contextualise a virtual physical and temporal space shared by the participants who understand that their messages can be received immediately:

\begin{tabular}{|l|l|}
\hline Ci vediamo martedì & See you Tuesday \\
\hline Ci vediamo in giro! & See you round! \\
\hline... ci vediamo a lezione d'italiano. & ... see you in Italian \\
\hline
\end{tabular}

\section{EFFECTS OF ASYNCHRONICITY}

The inherently asynchronous nature of email communication allows students individually to choose when and where to compose/respond to messages according to their personal situation and motivation. (Warschauer \& Kern, 2000). This possibility encouraged the participation of the whole gamut of students from the highly motivated to the timid. Furthermore, the fact that students had time to think about and construct their reponses allowed them to produce a more personal style of dialogue than they could in the context of classroom oral interaction, where the time to reflect on each contribution is necessarily limited. Due to its asynchronous nature, email seemed to have positive effects on the language produced by students who, in most cases, would have had the opportunity to consult dictionaries and textbooks prior to sending their messages. This was clear from messages in which we observed a higher level of grammatical organisation, stronger cohesion and a better progression of ideas with respect to in-class oral interaction. The following introductory message from a first year beginner, after only four weeks of lessons, demonstrates these aspects. The presence of the conditional mode and past tense forms (underlined in the original), which had not yet been taught in the course, lead to the conclusion that the student has consulted a textbook or other source in composing his introduction.

\begin{tabular}{|l|l|}
\hline Vorrei mi presentare a tutti & I would like to introduce myself to all the \\
studenti d'italiano d'ANU. Mi chiamo & students of Italian at ANU. My name is \\
WH, e ho ventitré anni; sono & WH, and I am 23 years old, I'm a \\
studente universitario. Habito a Canberra & university student. I live in Canberra \\
in una grande casa con la mia famiglia - & in a big house with my family - \\
la madre (che si chiama $J)$, il padre $(R)$, & my mother (whos e name is J), my dad (R), \\
la sorella $(W)$ e il fratello $(P)$. Questo è & my sister $(\mathrm{W})$ and my brother $(\mathrm{P})$. This is \\
il mio primo anno d'italiano, ma non è il & my first year of Italian, but it's not the first \\
primo anno di studio universitario. Ho già & year of university study. I've already \\
finito i miei studi di matematica, e questo & finished my studies in maths and this \\
anno insegno un po' alla questa università. & year I'm teaching a bit at this university. \\
\hline
\end{tabular}

It is possible that students had fewer distractions and the chance to check, rewrite and correct their messages before sending (Baron, 1984; Warschauer, 1999; Lapp, 2000) since the asynchronicity of email would support this. From the analysis of the exchanges, it is clear that in many cases students referred to the dictionary or textbook to verify the correct usage of lexis or grammar before posting their contributions. This is most apparent in messages which contain words, forms or expressions which had not yet been cove red in formal instruction. For example, one student used the idiomatic expressions $\grave{E}$ 
una domanda spinosa (It's a thorny issue) e sbagliando si impara (You learn from your mistakes). Another used forme alterate such as vocabolarietto (little dictionary) and erbaccia (weeds). One student explicitly describes her use of the dictionary:

\begin{tabular}{|l|l|}
\hline Parli dei verbi greci - beato te! & You talk about Greek verbs - lucky you! \\
"Eleipthen??" - mi sembra che si abbia & "Eleipthen??" - it seems to me that you \\
bisogno di un "lisp" per parlare greco & need a "lisp" to speak Ancient \\
antico (come con lo spagnolo). Ho cercato & Greek (like with Spanish). I looked up \\
la parola giusta di"lisp": il dizionario da & the word for "lisp": the dictionary gives \\
"lisca", ma quando faccio il rimando, & "lisca", but when I check the Italian side, \\
come sempre, "lisca" significa "fishbone"! & as I usually do, "lisca" means "fishbone"! \\
(Matteo, aiutami!) & (Matthew, help me!) \\
\hline
\end{tabular}

This comment serves to confirm the hypothesis that asynchronous communication has positive effects on the language produced and on the strategies students use in their language learning. Students not only have the opportunity to make use of a wider set of language-related resources (dictionaries, text books, etc.) but can also reflect together on particular lexical, syntactic, grammatical, pragmatic, etc. aspects of the language under instruction.

The bracketed request for assistance, directed to one of the instructors, can be taken as an index of the empowering nature of email communication. While it is clear that we have an extension of the classroom environment, we also see a shift in the power relationship between student and instructor. The student, in this case, is quite comfortable and direct in requesting help. This is perhaps not an unexpected development which needs to be factored into the choice to use CMC. It also highlights the student-centredness of the activity.

\section{HYBRID COMMUNICATION: WRITTEN-SPOKEN}

The hybrid nature of email communication is revealed by examining the aspects which relate to written versus oral interaction.

\begin{tabular}{|c|c|}
\hline Written communication & Oral interaction \\
\hline $\begin{array}{l}\text { - formal accuracy - morphological, } \\
\text { syntactic, lexical } \\
\text { - discourse coherence } \\
\text { - } \text { progression of ideas }\end{array}$ & $\begin{array}{l}\text { - unconventional use of punctuation } \\
\text { - } \text { and capital letters } \\
\text { - } \text { high frequency of questions } \\
\text { language of expressions from spoken }\end{array}$ \\
\hline
\end{tabular}

While the written aspects relate mostly to structural issues, the oral characteristics are clearly an attempt to make the communication both interactive and expressive. In some senses, the unconventional use of punctuation and other written symbols serves to compensate for the lack of visual cues. The analysis of the exchanges reveals that students made use of this hybrid type of communication to develop a type of oral-like interaction which would have been less possible in a classroom context either due to shyness or fear of making mistakes, or to perceptions of unequal standing within the ecology of the classroom. As we indicated in the opening of this study, previous work has shown that CMC promotes interaction due to a levelling of power differentials owing to the lack of visual and other cues which serve to reinforce hierarchies (Sproull \& Kiesler, 1991; Roes, 2003).

Baron holds that the use of email influences not only the range of ideas expressed but also the way in which they are expressed (Baron, 1984). As noted above, the 
asynchronous context clearly has the advantage of allowing students to fully develop their ideas resulting in messages which are more grammatically complex and coherent from a structural point of view. Baron's conclusions are confirmed by Harrington \& Levy (2000) who describe how the abilities which characterise communicative competence in an oral context manifest themselves very differently in an electronic context. It is however important to note that when students communicate electronically the style of interaction appears more spontaneous and natural, and in many ways more similar to a conversation when compared with other forms of written communication. This observation is confirmed by many studies which have examined email communication. Maynor (1994) and Bertocchi (1999) conclude that email communication represents a convergence between written and oral modes. Indeed, they describe how written conventions are subverted to better evoke a type of oral interaction. This includes a simplified orthography, emphatic or expressive use of upper and lower case letters and punctuation (for instance, exclamation marks).

Referring specifically to the current project, we noted that the convention of beginning each sentence with a capital letter was generally respected. Shield (p.c) points out that this could, in fact, be due to an automatic feature of the email editor the students used. Notably, no student abbreviated or simplified words, not even at advanced levels. Both of these features may reflect student perceptions of what is important for assessment requirements. In general, punctuation was conventional, however we did observe the consistent use of exclamation marks to convey emotional load.

Weininger \& Shield (forthcoming) present a frame for analysing CMC discourse which usefully extends the notion of using the spoken/written dichotomy. Referring to a German study by Koch \& Oesterreicher, they propose a "model which places all types of linguistic production on a continuum ranging from the language of proximity (Sprache der Nähe) to the language of distance (Sprache der Distanz)". In this framework, the horizontal axis moves from proximity to distance both figuratively and in space and time while the vertical axis covers specific communication contexts and coding strategies. This multidimensional model can represent in a more sophisticated fashion the relationship between email discourse and other modes of communication. In their discussion of MOO-discourse, Weininger \& Shield conclude that "both MOO-discourse and oral communication are indeed located close to each other, towards the proximate end of the continuum". To this end, MOO-discourse has more in common with oral communication than written discourse. Although, further investigation is required, we surmise that a similar case would hold for NNS email communication.

\section{EXPRESSIVITY}

We noted above that punctuation is frequently employed in email communication toconvey emphasis. Kitade comments that a "noticeable feature of [CMC] is the absence of non-verbal cues" (Kitade, 2000, p. 152). She identifies recourse to "a question mark '?' to express uncertainty, ellipsis '...' to show hesitation, smiley marks ':-)', etc. to show one's feelings, and capitalization or quotation marks to recast or emphasize a certain work/phrase of utterances". "Experienced participants", she continues "appear to compensate for such a lack of non-verbal cues using creative signals" (Kitade, 2000, p. 152). In our data, these methods for expressing that a message was "emotivamente carico" (Bertocchi, 1999) or emotionally charged are present. In the examples below we see the use of exclamation marks, capital letters and repetition to add colour: 


\begin{tabular}{|l|l|}
\hline Ho bisogno di una macchina!! & I need a car!! \\
\hline Sono in vacanza!!! Non ho lezione!!! & I'm on holidays!! I dont' have classes!!! \\
\hline Povero me!!!! & Poor me!!!! \\
\hline $\begin{array}{l}\text {...ho una presentazione domani e } \\
\text { due test!!!! }\end{array}$ & $\begin{array}{l}\text { I've got a presentation tomorrow and } \\
\text { two tests!!!! }\end{array}$ \\
\hline $\begin{array}{l}\text { Guardo due possume (POSSUMS??!??) } \\
\text { nel granaio. }\end{array}$ & $\begin{array}{l}\text { I see two possums (POSSUMS??!??) } \\
\text { in the loft. }\end{array}$ \\
\hline $\begin{array}{l}\text {...perchè c'e' la classe alle nove il } \\
\text { giovedi - alle nove - madonna! }\end{array}$ & $\begin{array}{l}\text {...because there's the class at nine on } \\
\text { Thursdays - at nine - Mother of God! }\end{array}$
\end{tabular}

However, expressivity is not only limited to typographical manipulations but also, and in our view more significantly, to the use of particular expressions which students have acquired in class, found in their text-book or simply copied from other emails they have received.

From the textbook

\begin{tabular}{|c|c|}
\hline Sono in ritardo. & I'm late \\
\hline Sono una ritardataria! & I'm a latecomer. \\
\hline \multicolumn{2}{|l|}{ From other sources } \\
\hline Scrivo questo alle ore piccole & I'm writing this in the wee hours \\
\hline Ero giovane e pronta a tutto! & I was young and ready for anything! \\
\hline Modestia a parte... & Modesty apart... \\
\hline ...perchè ho una montagna di lavoro. & ...because I have a mountain of work \\
\hline ...ma e' una domanda spinosa... & ... but that's a thorny issue... \\
\hline
\end{tabular}

All of the above appears to be an attempt to lend tone and feeling to a medium of communication which is intrinsically decontextualised - you do not see your interlocutor face to face, nor hear their voice or intonation as in an oral interaction. It could also be argued that students sought to compensate for the lack of gestural possibilities given that Italian is stereotypically recognised as a language which features this.

A notable example of creative expression can be seen in the following introductory message which carried the title "sex" in the subject field. This first year student clearly wished to attract the attention of the other participating students in order to begin an online interaction. The recourse to a catchy title came about after her first message had been ignored.

Subject: SEX...

Date: Tue, 28 Mar 2000 07:00:21 GMT Subject: SEX...

Date: Tue, 28 Mar 2000 07:00:21 GMT

Cari studenti d'italiano

Dear students of Italian

Scusi, la pubblicitá falsa - questo l'email

non discutere 'sex', ma descrivere mi.

Che peccato!

Excuse the false publicity - this email doesn't discuss "sex", ma describes me. What a pity!

14. THE RELATIONSHIP BETWEEN FORM AND CONTENT

The analysis of the emails exchanged allows us to reflect on the relationship between form and content. We note that in the emails which are less elaborate and less structured from a stylistic standpoint, the content is in general more banal and superficial, with little development or elaboration of ideas. Messages of this type were mostly (but not exclusively) exchanged by students in the beginners' level who had not yet developed the 
complex linguistic structures required to communicate and express themselves with originality and flair. In the case of more elaborately structured messages, we note a larger range of lexical choices as well as improved originality and coherence of content. There was greater continuity between the messages exchanged resulting in logical and coherent discussions of notable quality. We therefore identify a typological distinction between "pro forma exchanges" and "elaborate exchanges" as illustrated below. In the following exchanges, spelling mistakes are italicised and grammatical problems (such as lack of agreement, incorrect word order, use of incorrect form, etc.) are underlined.

\section{Pro forma exchanges}

\section{Exchange 1}

\section{Ciao a tutti!!}

Questa lettera e in ritardo- mi dispiace!

Mi chiamo KR e ho dicianove anni. Abito a Fenner

Hall- $e$ molto pazzesco!

Studio la storiadel'arte e l'italiano- mi piace queste. Anch'io studio la legge- $e$ molto noiosa e difficille. Ho padre, madre e una sorella. Si chiama Elei e molto felice. Ho due fratelli. Si

chiamano M e L. Ho un cane- si chiama J- $\underline{\text { lei }} \underline{\mathrm{e}}$ molto stupida ma curina.

A piu tardi,

KR

Buon giorno $\mathrm{K}$,

Mi chiamo EB (L). Ho venti anni. Sonno Canberra.

Abita con mia madre e padre e sorella. Mia

sorella si chiama R. Lei quattordici anni

Studo l'italiano, la chimica, la biologia e la geografia a ANU. La chimica $\underline{\text { e }}$ molto difficile e non interessante.

Lavoro la Canberra teatro. Io molto amore mia posto.

Ciao, a piu tardi, $\mathrm{L}$

Hi all!!

This letter is late- sorry!

My name is KR and I'm 19. I live in Fenner

Hall- it's very crazy!

I study art history and Italian- I like

these. I also study law- it's very boring and difficult.

I have a father, mother and sister. She's called Eshe's very happy. I have two brothers. They're called M \& L. I have a dog- her name is J-she's very stupid but cute.

See you later,

KR

Good day K,

My name's EB (L). I'm 20. I'm from Canberra. I live with my mother and father and sister. My sister's called R. She's 14.

I study Italian, chemistry, biology and geography at ANU. Chemistry is very difficult and not interesting.

I work at the Canberra theatre. I love my job.

Bye, see you soon, $\mathrm{L}$

\section{Exchange 2}

Ciao, Mi Chiamo LS. Sono in ritardo. Ho diciasette anni. Abito a Canberra, mada sono di Sydney. Abito Canberra otto anno. Studio

italiano, scieze politiche, l'inglese e europa $\underline{\text { studia. Ho cinque fratella, e tre sorrella, sono }}$ molte grande familgia. Io lavoro all liberia, Angus \& Robertson woden.

Ciao.

Ciao L! Mi chiamo D e ho diciannove anni. Dove a Canberra abiti tu? Abito a Curtin con mio padre.

Tua famiglia e' molte grande, ti piace tutti tuei fratelli e sorelle?

Le scienze politiche sono difficile?

Quando e' tuo compleanno?

Io non lavoro, ma sono in cerca un posto.

Studio l'italiano come tu, il francese, il tedesco e
$\mathrm{Hi}$, My name is LS. I'm late. I'm seventeen years old. I live in Canberra, but I'm from Sydney. I've been living in Canberra for eight years. I study Italian, political science, English and European studies. I have five brothers and three sisters, it's a very big family. I work at the bookshop, Angus \& Roberston in Woden.

See ya.

Hi L! My name is D and I am nineteen. Where in Canberra do you live? I live in Curtin with my dad. Your family is very large, do you like all of your brothers and sisters?

Is political science difficult?

When is your birthday?

I'm not working, but I'm looking for a job. I'm studying Italian like you, French, German and 


\begin{tabular}{|c|c|}
\hline $\begin{array}{l}\text { l'inglese all' universita'. } \\
\text { A presto! } \\
\text { D. }\end{array}$ & $\begin{array}{l}\text { English at uni. } \\
\text { See you soon! } \\
\text { D. }\end{array}$ \\
\hline $\begin{array}{l}\text { Ciao D, Sono molte in retardo a italiano oggi. } \underline{\text { Io }} \\
\text { motle retardo per l'esame. } \underline{\text { Italiano motle difficile da }} \\
\underline{\text { scienze politiche. Scienze politiche molte facile, }} \\
\text { italiano molte difficile. } \underline{\text { Oggi mio il compleanno }} . \underline{\text { Io }} \\
\text { diciotto anni. } \\
\text { Ciao D. }\end{array}$ & $\begin{array}{l}\text { Hi D, I'm really late to Italian today. I'm } \\
\text { really late for the test. Italian is more difficult than } \\
\text { political science. Political science is very easy, } \\
\text { Italian very hard. Today is my birthday. I'm } \\
\text { eighteen years old. } \\
\text { See ya D. }\end{array}$ \\
\hline $\begin{array}{l}\text { Ciao L! grazie per tua riposta. Desidaro te dire: } \\
\text { buon compleanno! Mi piace l'italiano perche' e' } \\
\text { molta bella lingua. E' come il francese, } \underline{\text { c'e' perche' }} \\
\text { e' facile per mi. Ma non lo so niente delle scienze } \\
\text { politiche! } \\
\text { Ci vediamo domani, } \\
\text { D. }\end{array}$ & $\begin{array}{l}\text { Hi L! Thanks for your reply. I want to say to you: } \\
\text { happy birthday! I like Italian because it is } \\
\text { a really lovely language. It's like French, that's why } \\
\text { it's easy for me. But I know nothing about political } \\
\text { science! } \\
\text { See you tomorrow, } \\
\text { D. }\end{array}$ \\
\hline
\end{tabular}

In these exchange between two dyads of beginners' level students, we note the following features:

- a limited range of topics - in fact, the exchange is almost exclusively dominated by closed question-response cycles based on the students' current studies

- usage of basic Italian grammar without any evidence of attempts at extending or enriching the dialogue with new structures or vocabulary

What this description reveals is perhaps a lack of serious engagement with the exercise on the part of these students. We can surmise that they did not take advantage of the asynchronous nature of email to draft their messages and check them before sending. In reality, there is very little dialogue between the students, the questions which are posed are superficial and the flow of the dialogue does not depend on the answers. This is very clear in exchange 1 where each student simply offers parallel monologues. Neither participant seems particularly interested in the other or in their situation. In exchange 2 , there is evidence of dialogue but this remains at a very superficial level.

\section{Elaborate exchanges \\ Exchange 3}

\section{Buona sera $\mathrm{K}$}

Come sta?

Non abbiamo parlare per poco tempo fa! Questo il secondo "email exchange" esercisio. Le piace parlare con me ancora una volta? Per questo esercisio devo mandare quattro messaggi. Forse discutiamo gli altri sogetti studia al'universita'?

$\mathrm{O}$ forse i viaggi d'Italia ieri anno, o altri paesi.

Forse ha veduto un buon film recentemente, o ha letto un buon libro? Non ho molto tempo leggere libri, ma mi piace

leggerre durante le vacanze.

Che cosa fa alla pasqua?

Che cosa fa di solito il sabato o domenica?

Ieri sera ho andato un concerto di "Australian Chamber Orchestra".

Il concerto e' stato molto speciale, e

\section{Good Evening K}

How are you?

We haven't spoken for a while!

This is the second "email exchange" exercise. Do you want to talk to me again? For this exercise I have to send four messages. Perhaps we can discuss the other subjects you study at University?

Or maybe the trips to Italy last year, or other countries.

Maybe you've seen a good film lately, or have read a good book? I don't have much time to read books, but I like reading during the holidays.

What are you doing for Easter?

What do you usually do on Saturday or Sunday?

Last night I went to a concert of the "Australian Chamber Orchestra". The concert was very special, and 
spetacolo- perche l'orchestra ha

suonata "Peter and the Wolf" di Prokofiev.

Era bellissima l'esecuzione e il

presentatore era Peter Garrett (dello gruppo

"Midnight Oil"). Gli disegni di Michael

Leunig. Anche l'orchestra ha suonata

"Carnival of the Animals" di Camille

Saint-Saens. Che bello concerto. Era

molto, molto simpatico!!

Ti piace ascoltare la musica da camera?

Forse abbiamo il caffe' al'universita' un giorno. Ho lezione d'Italiano ogni martedi, mercoledi e giovedi, alle mezzogiorno. Forse incontriamo un venerdi, alle mezzogiorno-

A presto

A

Ciao A

Penso que lei non abbia ricevuto mio e-mail che ho spedito venerdi'. Anche se ho premuto "reply", ora ho notato che mio messaggio e' andata a

"r@cyberone.com.au". Non so perche'. Sto mandando altra volte in questo messaggio ma questo tempo ho dattilografato $\underline{\text { sua }}$ indirizzo di lavoro.

Sono molto felice che stiamo continuando nostra communicazione.

Mi dispiace che non sono andata al concerto che mi ha mencionata.

Ovviamente e' stato fantastico. A volte vado ai concerti di musica da camera - $\mathrm{i}$ concerti di Musica Viva o concerti alla vecchia Parliament House.

Questa settimana mio marito ed io siamo andati al balletto "The Merry Widow" - era bellissimo! La danza, la musica, i costumi, $i$ sceni - tutto era molto bello.

Ha visto il film "American

Beauty"? Mi sembra che sia stato molto interessante e con molti aspetti che potremmo discutere. Per essempio, penso che il messaggio sia stato, alla fine, ottimista (perche il protagonista ha deciso cercare cose che erano importanti per lui stesso). Anche penso che sia stato molto divertente. Alcuni dei mei amici non sono d'accordo con me.

Se non ha visto "American Beauty", spectacular-because the orchestra

played "Peter and the Wolf" by Prokofiev.

The playing was really beautiful and the compere was Peter Garrett (of the group "Midnight Oil"). The designs by Michael

Leunig. The orchestra also played

"Carnival of the Animals" by Camille

Saint-Saens. What a great concert. It was really, really nice!!

Do you like listening to chamber music?

Perhaps we can have a coffee at university one day. I have Italian every

Tuesday, Wednesday and Thursday, at

midday. Perhaps we can meet one

Friday, at midday-

Talk soon

A

Hi A

I think you didn't receive my email that I sent on Friday. Even though I pressed "reply", I've just noticed that my message went to

"r@cyberone.com.au" I don't know why.

I'm sending this message again

but this time I've

typed your work address.

I'm very happy that we' re continuing our communication.

I'm sorry that I didn't go to the concert that you mentioned to me.

Clearly it was fantastic. Sometimes I go

to chamber music concerts - Musica Viva concerts or concerts at Old

Parliament House.

This week my husband and I went to the ballet "The Merry Widow" - it was great! The dancing, the costumes, the sets everything was really beautiful.

Have you seen the film "American

Beauty"? I think it was very

interesting and has many aspects that

we could discuss. For example, I think

the message was, in the end, optimistic

(because the protagonist decided to look for things that were important to him).

I also think that it was entertaining.

Some of my friends don't agree

with me.

If you haven't seen “American Beauty”, 
possiamo parlare di una o $p u i^{\prime}$

dei soggetti che ha suggerito.

Il martedi' ho una lezione da $2.00 \underline{\mathrm{a}}$

3.00 e il giovedi' $\underline{\text { da }} 9.00$ a 11.00 .

Quindi possiamo prendere un cafe ante or

doppo la sua lezione. $\mathrm{O}$, se $e$ piu' facile per

lei, possiamo incontrare un venerdi' $\underline{\text { al }}$

mezzagiorno.

A piu' tarde

K

\section{Grazie K}

Penso e' meglio per andare il suomessagio a indirizzo di lavoro. Ho molto difficili con mio email indirizzo a casa. Dunque, usiamo questo indirizzo, va bene?

Anch'io, sono molto felice che stiamo continuando nostra communicazione. Il baletto "The Merry Widow" mi sembra anche una fantastica esperienza! Non vado al baletto spesso, ma mi piace andare ogni tanto, per la varieta. Ma, mio marito non piacciono baletti molti, dunque, non andiamo spesso. Preferiamo la musica da camera o l'orchestra.

$\underline{\text { Sabato scorso sera, siamo andato al concerto }}$ alla vecchia Parliament House, per la festa di musica da camera. Sa la festa di

musica da camera? E'ogni anni a Canberra, a maggio. Il concerto era bellissimo! Anche, questo venerdi andiamo altro concerto, $\underline{\mathrm{di}}$ Australian Chamber Orchestra, con la cantante Yvonne Kenny. E poi, questa domenica sera, andiamo altro concerto alla vecchia Parliament House, per la festa. Siamo molto impegnato questa il fine settimana, ma i concerti sono molti simpatici! D'accordo?

Ho visto il film, "American Beauty", tre mesi fa. E' un buon film, particolarmente per un film d'americano. Non mi piacciono semp re i film d'americani. Io preferisco un film d'inglese, d'italiano o di francese. Ma penso "American Beauty" e' molto aspetti; $\underline{\text { ha commedia ed anche tragedia }}, \underline{\mathrm{e}}$ discrive la situazione di umano.

Penso in questo film, Kevin Spacey e' un attore dinamico, ed anche questo film ha molti aspetti di famiglia vita, di lavoro e $\underline{\text { di }}$ vita moderna.

Ha vista altri film? Spesso vedo i film, we can talk about one or more

of the subjects that you suggested.

On Tuesdays I have a class from 2.00 to 3.00 and on Thursdays from 9.00 to 11.00 . So we can have a coffee before or after your class. Or, if it's easier for you, we can meet one Friday at midday.

Talk soon

K

Thanks K

I think it's better to send your message to the work address. I have a lot of problems with my home email address. So, let's use this address, is that ok?

I'm really happy that we're continuing our communication too. “The Merry Widow" ballet sounds to me like a fantastic experience! I never go to the ballet often, but I'd like to go every now and then for variety. But my husband doesn't like ballet much, so, we don't go often. We prefer chamber music or the orchestra.

Last Saturday night, we went to the concert at Old Parliament House, for the festival of chamber music. You know the festival of chamber music? It's every year in Canberra in May. The concert was great! Also, this Friday we're going to another concert: the Australian Chamber Orchestra with the singer Yvonne Kenny. And then, this Sunday night, we're going to another concert at Old Parliament House for the festival. We're very busy this weekend, but concerts are so nice! Don't you agree?

I saw the film, "American Beauty", three months ago. It's a good film, particularly for an American film. I don't always like American films. I prefer an English, Italian or French film. But I think "American Beauty" has many sides; it has comedy and also tragedy, it describes the human condition.

I think in this film Kevin Spacey is a dynamic actor, and also this film has many aspects of family life, of work and of modern life.

Have you seen other films? I see films often 
dunque posso discutere altri film.

E' piu' facile per me incontrare un venerdi' al mezzogiorno. Forse prossima settimana, o l'altro settimana?

a presto

A

Ciao A

Va bene. Usaro' il suo indirizzo di lavoro.

Altri anni ho assistito alla festa di musica da camera ma non posso quest'anno. Il concerto con Yvonne Kenny sara', senza alcun dubbio, meraviglioso. Mio marito non piace molto il balleto ma era felice venire a "The Merry Widow" perche' gli piace la musica di Lehar.

Come lei, non mi piace molto, generalmente, i film americani - "American Beauty" era $\underline{u n}$ eccezione. Mi sembra che era molto intelligente, era serio, era divertente ed

era un po' bizzarro (mi piaceva molto il sacco di plastica!). Si, sono d'accordo che Kevin Spacey era molto buono in questo ruolo.

Mi piace anche i film francese. Ho visto due durante l'ultimo mese - "An Autumn Tale" e "The Dinner Game". Non mi piace molto il secondo ma "An Autumn Tale" era molto buono - uno di questi film francesi dove non succede molto ma $\mathrm{e}^{\prime}$ affascinante. Ha visto?

$S i$, posso incontrarle venerdi' 26 Maggio (la prossima settimana).

Se mi spedira' un e-mail doma ni per la mattina, rispondero' nel pomeriggio.

A presto

$\mathrm{K}$

Buon giorno K!

Che settimana! Sono molto impegnato al lavoro ed anche molto impegnato a casa! Ma questa fine settimana era bellissima . Venerdi sera siamo andato al concerto di Australian Chamber Orchestra con Yvonne Kenny, con mio marito ed anche con mio padre e mia madre. Mio padre gli piace Yvonne Kenny moltissima! Il concerto e' stato buonissimo, e' elegante e molto simpatico. Ha cantato "Les nuuits" di Berlioz. La musica e' stato molto romantica. L'orchestra anche suona la musica di Haydn e Ravel. Bellissima! L'orchestra e' so we can talk about other films.

It's easier for me to meet on Fridays at midday. Maybe next week or the week after?

see you soon

A

Hi A

Ok. I'll use your work address.

In other years I've gone to the chamber music festival but I can't this year. The concert with Yvonne Kenny will be, without a doubt, marvellous. My husband doesn't like ballet much but he was happy to come to "The Merry Widow" because he likes Lehar's music.

Like you, in general, I don't really like, American films - "American Beauty" was an exception. I think that it was very clever, it was serious, it was entertaining and it was a bit odd (I really like the plastic bag!). Yes, I agree that Kevin Spacey was very good in this role.

I also like French films. I've seen two in the last month - "An Autumn Tale" and “The Dinner Game". I didn't like the second one much but "An Autumn Tale" was really good - one of those French films where nothing much happens but it's fascinating. Have you seen it?

Yes, I can meet you on Friday 26 May (next week).

If you send me an email tomorrow in the morning, I'll reply in the afternoon.

Talk soon

$\mathrm{K}$

\section{Good day K!}

What a week! I'm really busy at work and very busy at home! But the weekend was lovely. Friday night we went to the Australian Chamber Orchestra concert with

Yvonne Kenny, my husband and also my father and my mother. My father likes Yvonne Kenny a lot! The concert was excellent, it was elegant and very nice. She sang "Les nuuits" by Berlioz. The music was very romantic. The orchestra played the music of Haydn and Ravel. Beautiful!The orchestra is 
brillante. Penso siamo fortunati avere questa orchestra visita a Canberra spesso.

E poi, sabato sera ho cucinato cena per dieci amici! (Oggi sono molto stanco, perche non dormiro fino a domenica mattina, alle due.) Sta sera siamo andare altro concerto per la festa di musica da camera, alla "Old Parliament House". Ma andare ai concerti $\mathrm{e}^{\prime}$ buon divertimento, e mi piace andare quando e' possibile

Ha visto "A Midsummer night's dream"? Spero andare questa settimana, forse mercoledi' sera, dopo lavoro. Ma, se non vado, forse vado al cinema

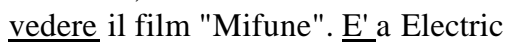
Shadows per due settimane, solo. Penso abbiamo molto buon e prima qualita divertimento a Canberra, d'accordo?

Pero', oggi devo studiare l'italiano; e' fortunata studio una materia al'universita questo anno. Perche', anche mieifigli studiamo $a l$ 'universita di ANU, mia famiglia e' molto occupato. Ma penso avere molto occupato e' meglio.

Mi piace incontrare venerdi', ventisei maggio (questa settimana, alle mezzogiorno).

Telefono questa settimana, forse mercoledi' o giovedi'.

A presto

A

Ciao A

$S i$, ho recevuto il suo ultimo messagio due volte - spero che questo significa che il suo email a casa funciona meglio!

La sua fine settimana mi sembra era molto bella. Tanto bella musica!

Io ho passato una fine settimana molto tranquilla perche' mio marito e' andato via (a Coffs Harbour) per una settimana. $\underline{\text { La fine }}$ settimana prima dell'ultima era anche molto tranquilla perche ho assistato ad un corso di meditazione in la tradizione del buddismo di Tibet. Ho imparato "Transcendental Meditation" in Buenos Aires in 1974 (questa forma della meditazione era molto populare in questo tempo). Daquando, continuavo meditando con molte pause. La filosofia del buddismo specialmente il buddismo di Tibet - e' come una scienza del mente. A volte, quando ci brilliant. I think we are really fortunate to have this orchestra visit Canberra often.

And then, Saturday night I cooked dinner for ten friends! (Today I'm very tired, because I didn't go to be until Sunday at two in the morning). Tonight we are going to another concert of the chamber music festival at "Old Parliament House". But going to concerts is good fun and I like going when it's possible.

Have you seen "A Midsummer night's dream"? I hope to go this week, maybe Wednesday night, after work. But, If I don't go, maybe I'll go to the movies to see the film "Mifune". It's on at Electric Shadows for two weeks only. I think we have good, top quality entertainment in Canberra, don't you agree?

But, today I have to study Italian; it's lucky that I only study one subject at University this year. Because my children study at ANU as well, my family is very busy. But I think being very busy is best.

I'd like to meet Friday 26May (this week, at midday).

I'll ring this week, maybe Wednesday or Thursday.

Talk soon

A

Hi A,

Yes, I received your last message twice - I hope that this means that your home email is working better!

Your weekend sounds like it was really lovely. So much beautiful music!

I had a very quiet weekend because my husband went away (to Coffs Harbour) for a week. The weekend before last was also very quiet because I attended a course in meditation in the Buddhist tradition of Tibet. I learnt "Transcendental Meditation" in Buenos Aires in 1974 (this form of meditation was very popular at that time). Since then, I've continued meditating with lots of breaks. Buddhist philosophy especially from Tibet- is like a science of the mind. Sometimes, when a 
sono un monaco buddista vistando Canberra vado a ascoltarlo. E lei? Ho practicata mai una forma della meditazione?

$\underline{\text { In }}$ suo corso d'italiano ha un esame al fine della questa semestre? Noi non abbiamo un esame, grazie a Dio! Nell'ultimo anno (primo anno), abbiamo avuto un essame molto facile dopo la prima semestre e un esame molto difficile $\underline{\text { al fine del secondo }}$ semestre. Non e' dire che sara' lo stesso quest'anno.

Posso incontrare venerdi a $12.30 \mathrm{pm}$. Va bene? Le telefonaro' mercoledi'. (E' meglio se io teleofonaro' perche' a molte volte non sono a casa.) Possiamo andare $\underline{\text { in }}$ qualche parte circa al tuo lavoro.

A presto

$\mathrm{K}$

Buon giorno $\mathrm{K}$

$\mathrm{Si}$, mio scorsa fine settimana era bella! Non penso $\underline{e}^{\prime}$ possibile avere troppa bella musica, e' vero? Pero', perche' sono molto impegnato al lavoro (ho lavorato troppi ori per molti settimani) ed a casa, $\underline{\text { io }}$ stanca. Adesso, oggi sto male (ma, non troppe male). Mi dispiace, ma, non e' possibile incontrare domani (ie venerdi alle mezzogiorno, ventisei maggio). Forse', incontriamo prossima settimana? Oggi io non a lavoro, sono a casa.

Coffs Harbour e' lontana da qui, ma non e' lontana dal luogo ho abitato molto tempo fa. Ho abitato Nambucca Heads, e' bello luogo, quando ero giovane. Non lo so di meditazione, ma penso e' molto buono per rilassamento. Qualche tempo fa, ho imparato "Tai Chi", perche' ho avuto una ferita. Ha aiutato e ho imparato per due anni, ma adesso nuoto invece di "Tai Chi". $\underline{\mathrm{Ho}}$ piaciuto l'attivita di "Tai Chi", ma io non avere molti pazienza. (Imparare l'italiano $\mathrm{e}^{\prime}$ buona attivita per me, perche' e' difficile se $e^{\prime}$ non pazienza!) Ma, mio marito practica "Tai Chi" per molti anni. Non sono una buona studentessa di meditazione; non avere mente tranquille o buone concentrazione.

Ammiro gente chi capiscono meditazione perche' e' importante avere una forma di rilassamento. Tutto di religioni e filosofia del mondo, penso buddismo e' maggior etico. Qualche tempo fa, ho visto
Buddhist monk visits Canberra

I go to hear him. What about you? Have you

ever practised a form of meditation?

Does your Italian course have an exam at the end of this semester? We don't have an exam, thank God! Last year

(first year), we had a really easy exam

after the first semester and a

really difficult exam at the end of the second semester. That's not to say that it will be the same this year.

I can meet you on Friday at $12.30 \mathrm{pm}$. Is that ok? I'll phone you on Wednesday. (It's better if I phone because I' $m$ not home a lot of the time). We can go

somewhere close to your work.

See you soon

$\mathrm{K}$

Good day K

Yes, my weekend was lovely! I don't think it's possible to have to much beautiful music, do you? Anyway, since I'm so busy at work (I have worked too many hours for many weeks) and at home, I'm tired. Now, I'm sick today (but not too sick). I'm sorry, but, it's not possible to meet tomorrow (ie Friday at midday, 26 May). Maybe we can meet next week? Today I'm not at work, I'm at home.

Coffs Harbour is far from here, but it's no $\mathrm{t}$ far from the place I lived a long time ago. I lived in Nambucca Heads, it's a beautiful place, when I was young. I don't know about meditation, but I think it's very good for relaxation. A while ago I

learnt "Tai Chi", because I injured

myself. It helped and I learned for two years, but now I swim instead of "Tai Chi”. I liked doing "Tai Chi”, but I don't have much patience. (Learning Italian is a good activity for me, because it's difficult if you're not patient!) But, my husband has practised "Tai Chi” for many years. I'm not a good student of meditation; I don't have a peaceful mind or good concentration.

I admire people who know meditation because it's important to have a form of relaxation. Of all the religions and philosophies in the world, I think Buddhism is the most ethical. A while ago, I saw 
un monaco buddista a Lyneham, vedere una manifestazione di Tai Chi.(Non mi piace "Western" religione, forse' sono agnostica)

Invece di medita zione, ogni giorni secondi, vado alla piscina e nuoto. Esco a casa alle sette e mezzo nella mattina (d'inverno $\underline{\mathrm{e}:}$ molte difficile perche' $\underline{\mathrm{e}}$ molto freddo). Mi piace molto nuotare, ogni mesi d'anno. E' buona forma della rilassamento per me, perche' mi piace pensare mentre nuoto. Nuotare $\underline{e d}$ anche una buona attivita per mia forma, ed posso andare solo. Anche, mentre nuoto e' possibile imparare i verbi italiani e i numeri italiani ... uno, due, tre ..ecc. Pero', il nuoto e' buono per gli studenti d'italiano, particolarmente nuota trenta o trenta cinque giri della piscina!

Non nuoto oggi perche' sto male.

Adesso, oggi ascolto la musica di Tallis,

"Mass for four voices". E'

bellissima musica e tranquilla.

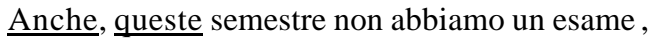
d'accordo- grazie a Dio! Non mi piace avere esame; sono troppa nervosa e

dimentico i verbi, i numeri, I nomi .tutti!

Telefono al piu' presto. Possiamo andare prossima settimana, e decidiamo incontrare in qualche parte. A presto

A

Ciao A

Non sono s orpresa che sta un po' male' non e' buono lavorare tanto per molti settimani. $\mathrm{Si}^{\prime}$, possiamo incontrare la prossima venerdi' (2 junio) alla Street Theatre Cafe. E' meglio anche' per me.

Dovrei tratare una forma di meditazione altra volte. Tai Chi e' una forma. Sono molto. Non e' necessario avere $\underline{\text { un }}$ mente tranquillo o la buona concentrazione. Certamente io non ho queste qualita' - al contrario! Ho comminciato e' fermato meditare molti tempi. Ma quando ho cominciato di nuovo ho sempre trovato che mi ha portato una mente molto piu' calma dentro dipocchi giorni. Anch'io credo che la filosofia buddista e' molto buona. Non sono una buddista ma mi piace molto molti degli principi di questo religione.

Non mi piace nuotare - specialmente perche non mi piace l'agua freddo - specialmente al vierno! Come tu, mio marito piace molto a Buddhist monk at Lyneham, I saw a

Tai Chi demonstration. (I don't like

Western religion, perhaps I' $m$ agnostic)

Instead of meditation, every second day I go

to the pool and swim. I leave home at 7.30

in the morning (in Winter it's very hard because it's very cold). I like swimming a lot, every month of the year. It's a good form of relaxation for me, because I like thinking while I swim. Swimming is also a good activity for my physique, and I can go alone. Also, when I swim it's possible to learn Italian verbs and numbers...uno, due, tre ..ecc. So, swimming is good for Italian students, particularly swimming 30 or 35 laps of the pool!

I'm not swimming today because I'm sick. Now, I'm listening to the musics of Tallis today, "Mass for four voices". It's beautiful, peaceful music.

We don't have an exam this semester either, I agree - thank God! I don't like having exams; I'm too nervous and forget verbs, numbers, nouns..everything! I'll ring soon. We can go next week, and decide to meet somewhere. Talk soon

A

Hi A

I'm not surprised that you are a bit sick it's not good to work so much for many weeks. Yes, we can meet next Friday (June 2) at the Street Theatre Café. It's better for me as well.

You should try a different form of meditation sometime. Tai Chi is one form. There are many. You don't need to have a peaceful mind or good concen tration I certainly don't have these qualities - au contraire! I've started and stopped meditating many times. But when I have started again I've always found that it gives me a much calmer mind within a few days. I also believe that the Buddhist philosophy is very good. I'm not a Buddhist but I like many of the principles of this religion.

I don't like swimming - especially because I don't like cold water - especially in Winter! Like you, my husband likes to swim 


\begin{tabular}{|c|c|}
\hline $\begin{array}{l}\text { nuotare e mi ha spesso detto che e' una } \\
\text { buona forma di rilassamento (come una } \\
\text { forma di meditazione me lo dice!). Che } \\
\text { buono che possa practicare i verbi italiani } \\
\text { nella piscina! }\end{array}$ & $\begin{array}{l}\text { a lot and he's always said that it's a } \\
\text { good form of relaxation (like a } \\
\text { form of meditation he tells me!). How } \\
\text { good to be able to practise Italian verbs } \\
\text { in the pool! }\end{array}$ \\
\hline $\begin{array}{l}\text { Alloro, e' interessante che anche lei non } \underline{\text { ha }} \\
\text { un esame quest'anno. Anch'io sono sempre } \\
\text { molto nervosa negli esami. Non mi piace } \\
\text { molto anche l'orale - specialmente } \underline{\mathrm{i}} \text { domandi } \\
\text { dopo la presentazione. Non ho ancora scelto } \\
\text { un soggetto per la mia seconda } \\
\text { presentazione.. }\end{array}$ & $\begin{array}{l}\text { So, it's interesting that you don't have } \\
\text { an exam this year. I'm also always } \\
\text { very nervous in exams. I don't like } \\
\text { the oral either - especially the questions } \\
\text { after the presentation. I haven't chosen } \\
\text { a topic for my second } \\
\text { presentation yet.. }\end{array}$ \\
\hline $\begin{array}{l}\text { Spero che senti meglio fra poco. Vediamo la } \\
\text { prossima venerdi'! } \\
\text { A presto } \\
\mathrm{K}\end{array}$ & $\begin{array}{l}\text { I hope you feel better soon. See you } \\
\text { next Friday! } \\
\text { Talk soon } \\
\text { K }\end{array}$ \\
\hline
\end{tabular}

\section{Exchange 4}

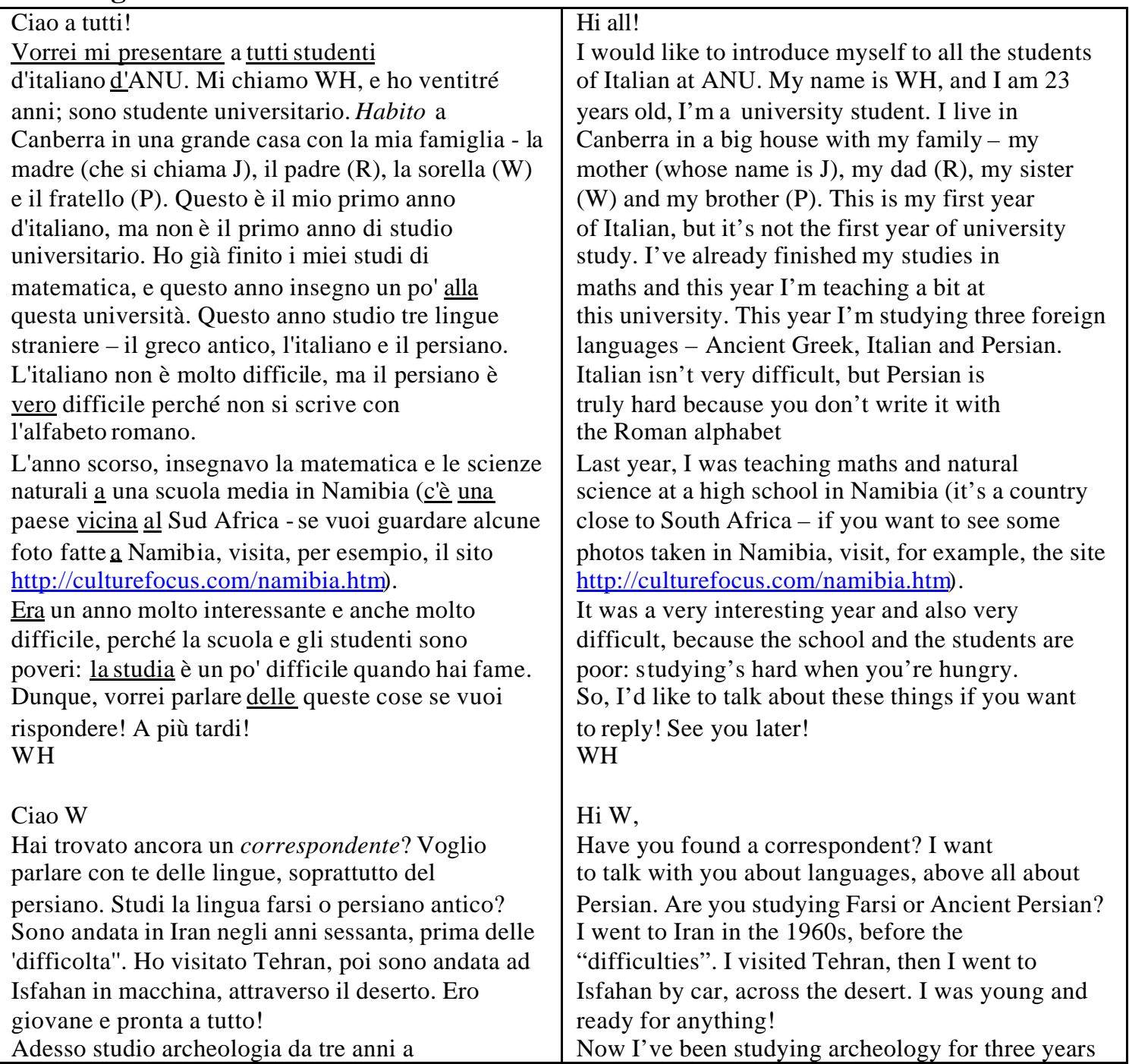


ANU, questo e' il mio secondo anno d'italiano. Quanto all'italiano, temo che io sia dilettante! Ho anche il lavoro a pieno tempo.

Molti anni fa, studio le civilta' asiatiche, anche a ANU. W, se ti piacerebbe, rispondimi. Dimmi tutto!

EC

Ciao E,

Grazie per la tua risposta! Non ho trovato ancora un correspondente ma va bene, perché mi piace parlare con te. Studio farsi, non persiano antico (che peccato!), ma ad ANU si chiama 'Persian' - perché, non conosco precisamente. Posso parlare un po' di farsi: lo studio da quattro settimane sole. Mi piacerebbe che parlassi un po' della tua visita in Iran. Perché sei andata? Che hai veduto? Era bello? Puoi parlare farsi, o hai diminticato?

Che cos'è il tuo lavoro?

Aspetto già la tua risposta prossima.

A presto!

W

\section{Buona giornata, $\mathrm{W}$ !}

No, non ti ho risposto prima, questa e' la mia seconda risposta. Calmati, non da' torto al computer, questa volta! Sono io in ritardo! Il mercoledi sera bisogna finire i miei compiti italiani (alla mezzanotte), perche' c'e' la classe alle nove il giovedi - alle nove - madonna! Ho passato solo una settimana in Iran, tornavo dall'Europa in Australia.

La moschea ad Isfahan era favolosa - che belle tegole blu - pero', purtroppo, non avevo la possibilita' di visitare Persepolis al sud. A casa, in qualche parte, c'e' il vocabolarietto $\underline{\text { da }}$ farsi, ma non lo parlo. Il mio lavoro e' la nostra impresa "Mr Spokes' Bike Hire", lungo Largo Burley Griffin, c'e' anche li' un piccolo caffe'. Dimmi del tuo anno in Namibia, W. Che anni hanno gli studenti? Si parla li' quali

lingue? Il tuo soggiorno $\underline{\text { e' }}$ organnizato da un gruppo internazionale? (come Community Aid Abroad, Peace Corps - esiste ancora..?) Questo e' un esercizio stupendo, no? (stupendo, non

stupido....!)

Con amichevoli saluti

E

Ciao, E!

Grazie per la tua ris posta scorsa. Sono difficile, i tui compiti italiani?

Sono io che rispondo adesso in ritardo, perché avevo molti compiti difficili di persiano. Questa lingua è sempre difficile perché ci sono nel nostro at ANU, this is my second year of Italian.

As for Italian, I fear I am an amateur! I'm also working full-time.

Many years ago, I was studying Asian civilisations, here at ANU as well. W, if you'd like, reply to me. Tell me everything!

EC

Hi E,

Thanks for your reply! I haven't found a correspondent yet but that's okay, because I like talking to you. I'm studying Farsi, not Ancient Persian (what a shame!), but at ANU it's called 'Persian' - why, I'm not precisely sure. I can speak a bit of Farsi, I've only been studying it for four weeks. I'd like you to talk a bit about your visit to Iran. Why did you go? What did you see? Was it good? Can you speak Farsi, or have you forgotten?

What's your job?

I'm already waiting for your next reply.

See you soon!

$\mathrm{W}$

Good day, W!

No, I didn't reply to you before, this is my second response. Settle down, don't blame the computer, this time! I'm the one who's late! Wednesday nights I have to do my Italian homework (at midnight), because there's the class at nine on Thursdays - at nine - Mother of God! I only spent a week in Iran, I was on my way back from Europe to Australia.

The mo sque at Isfahan was fabulous - what beautiful blue tiles - however, unfortunately, I didn't have the chance to visit Persepolis in the South. At home somewhere I have a little Farsi dictionary, but I don't speak it. My job is our enterprise "Mr Spokes' Bike Hire", along Lake Burley Griffin, there's also a little caffè there. Tell me about your year in Namibia, W. How old are the students? Which languages do they speak there? Was your trip organised by an international group (like Community Aid

Abroad, Peace Corps - does it still exist?). This is a stupendous exercise, isn't it? (stupendous, not stupid....!)

With warm wishes

$\mathrm{E}$

Hi, E!

Thanks for your last reply. Is your

Italian homework difficult?

I'm the one who's replying late now because

I've had lots of difficult Persian homework. This language is always hard because in our group there 
gruppo alcuni parlanti dell' araba che possono parlare molto velocemente, mentre io tento leggere una parola sola! Si dice, sbagliando s'impara, e spero che questo proverbio è vero! In Namibia, abitavo a un paese (quasi 2000 abitanti) che si chiama Tses. È nel sud di Namibia nel deserto - potevo guardare le sabbie dalla mia finestra. Gli studenti hanno da $13 \underline{a}$ 19 anni, e parlano il nama (una lingua molto difficile - la prononcia! I 'clicks'! (non conosco la parola italiana)) e anche l'afrikaans (di solito parlano l'inglese solo alla scuola). WorldTeach (un gruppo internazionale ma fondato a Boston) a organizato tutto.

Dimmi, se ti piace, di tu! Dove

abiti? Quanti anni hai (quasi!)? Che studi all'università?

A presto!

W

Buona sera, $\mathrm{W}$

Scrivo questo alle ore piccole, sono veramente grata alla posta elettronica! Il nostro lavoro e' molto occupato la settimana scorsa, certo siamo contenti (i soldi sono sempre benvenuti), ma- che stanchezza! Anche troppi verbi italiani irregolari! No, non trovo difficile la lingua italiana, pero' e' una sfida certa! Fortunatamente studiavo latino e francese a scuola e perfino all'universita' (cento anni fa). Il studio della lingua, come l'archeologia, e' un gran bel mistero, un indovinello. Qualche volta, per me resta un enigma, ma sempre, sempre m'interessa.

Ho cinquantasei anni, esattamente, non quasi! Studio archeologia da tre anni. Ad

ANU abbiamo la fortuna di avere i professori famosi e bravi - sei d'accordo? Quest'anno studio l'archeologia delle Ande Centrale, e mi sembra che la costa di Namibia sia dello stesso tipo della costa di Peru', cioe', si trova il mare molto freddo vicino al deserto. Come vedi, quale che m'interessa e' l'influenza sulla storia del clima. Il mare li' e' ricco di pesce? Mi ricordo di aver studiato i San e i Khoisan l'anno scorso.

Che cattiva, scrivo troppo! W, non credo che quest'anno sia il tuo primo d'italiano - scrivi facilmente (potrei dirlo), usi perfino il congiuntivo imperfetto, che bravo! Modestia a parte, dammi il segreto, sei uno studente brillante, davvero?!

A domani

E

Ciao, E!

Sono anche un po' stanco perché studio molto - ho due esami di greco antico questa settimana, e ho are some speaker of Arabic who can

talk really quickly, while I'm trying to read just one word! They say, you learn from your mistakes, and I hope this proverb is true! In Namibia, I was living in a town (about 2000 inhabitants) called Tses. It's in the South of Namibia in the desert - I could see the sand from my window. The students are between 13 and 19 years old, and they speak Nama (a very difficul language - the pronunciation! The 'clicks'! (I don't know the Italian word)) and also Afrikaans (they usually only speak English at school). WorldTeach (an international group but founded in Boston) organised everything.

Tell me about yourself, if you like! Where do you live? How old are you (almost!)? What are you studying at uni? See you soon! W

Good evening, W

I'm writing this in the wee hours, I'm really grateful to electronic mail! Our work was really busy last week, of corse we're happy (money is always welcome), but - how tiring! Also, too many irregular verbs.

No, I don't find the Italian language difficult, but it's certainly a challenge! Fortunately I studied Latin and French at school and even at university (100 years ago). The study of a language, like archaeology, is a big, lovely mystery, a riddle. Sometimes, for me it remains an enigma, but it always, always interests me.

I'm fifty-six years old, exactly, not almost! I've been studying archaeology for three years. At ANU we have the fortune to have famous expert lecturers - do you agree? This year I'm studying the archaeology of the Central Andes, and I think that the coast of Namibia is the same type as Perú's coast, that is, you find very cold sea near the desert. As you can see, something that interests me is the influence of history on climate. Is the sea there full of fish? I remember studying the San and the Khoisan last year. What a bad girl, I write too much. W, I can't believe that this is your first year of Italian - you write easily (I could say so), you even use the imperfect subjunctive, well done! Modesty apart, tell me you secret, you're a brilliant student, aren't you?!

'Til tomorrow E

$\mathrm{Hi}, \mathrm{E}$ !

I'm a bit tired too because I study a lot - I've got two tests for Ancient Greek this week, and I'm 
paura che siano difficile. Devo anche imparare molti verbi irregolari- 'leipo, leipso, elipon, leloipa, leleimmai, eleiphthen'; la verba greca ha tante forme ... e anche ho bisogno di studiare venti pagine del testo per tradurre. Ma non è troppo difficile perché, come hai detta, ci sono alcuni professori bravi ad ANU!

Non cognosco la costa di Peru (eccetto dalle fotografie), ma la costa di Namibia è veramente meravigliosa. A Swakopmund, per esempio, la pioggia è circa $20 \mathrm{~mm}$ per anno, e puoi vedere gli alberi e l'erba verde nella città, ma fuori, le sabbie del deserto.

Ci sono le piccole piante, 'weltwitschie', che somigliano a niente di speciale, ma possono vivere 500 anni o più nel questo deserto, perché hanno una radica di quasi cinquanta metri che beve dall'acqua sotteranea. E parli accuratamente dell'influenza del clima sulla storia - la parola nama '!namib' significa davvero 'scudo' in italiano; il deserto si chiama 'Namib' perché proteggeva il paese degli europei fino $\underline{\mathrm{a}}$ 1886.

Grazie per le tue frase simpatice della mia scrittura italiana, e la parola falsa 'brillante', ma è davvero il mio primo anno d'italiano! Congetturo la grammatica - studio il latino da dieci anni e cognosco anche un po' di francese - ma ho paura che in italiano faccia molti sbagli! Non c'è un segreto!

Hai parlato dei professori bravi ad ANU - chi sono? E perché diresti che sono tanti bravi? E (più importante, magari?) che hai fatto questa fine-settimana? Era buona? Buona sera! mihi est dormiendum, come i romani antichi dicevano!

$\mathrm{W}$

Buon pomeriggio, $\mathrm{W}$ !

Parli dei verbi greci - beato te!

"Eleipthen??" - mi sembra che si abbia bisogno di un "lisp" per parlare greco antico (come con lo spagnolo). Ho cercato la parola giusta di "lisp": il dizionario da "lisca", ma quando faccio il rimando, come sempre, "lisca" significa "fishbone"! (Matteo, aiutami!)

Lunedi' scorso ci siamo fermatia dormire dai parenti, vicino al Lago Illawarra alla costa. Ci sono piaciute due belle giornate limpide con viste stupende - una pausa piccola ma piacevole. Fai riferimento alla pianta "weltwitschie" che vive nel deserto. Credo che ci siano le rane australiane che iberano da molti anni, fino alla pioggia (beh, cinque anni, non 500!). Hai studiato botanica?

Quanto a me, non ho studiato mai le scienze (ecetto un po' di zoologia a scuola). Mi vergogno - non ne scared they'll be difficult. I also have to learn lots of irregular verbs - 'leipo, leipso, elipon, leloipa, leleimmai, eleiphthen', the Greek verb has many forms.... and I also need to study twenty pages of text for translation. But it's not too difficult because, as you said, there are some good lecturers at ANU!

I don't know the coast of Peru (except from photographs), but the Namibian coast is really marvellous. In Swakopmund, for instance, the rain is around $20 \mathrm{~mm}$ per year, and you can see trees and grass in the city, but outside, the sands of the desert.

There are little plants, 'weltwitschie', that don't look like anything special, but can live for 500 years or more in this desert, because they have a root of almost 50 metres that drinks from subterranean water. And you talk accurately about the influences of climate on history - the word nama '!namib' really means 'shield' in Italian, the desert is called 'Namib' because it protected the country from the Europeans until 1886.

Thanks for your nice sentences about my Italian writing, and the false word 'brilliant', but it really is my first year of Italian! I guess the

grammar - I've been studying Latin for ten years and I also know a bit of French - but I fear that in Italian I make lots of mistakes. There is no secret!

You talk about the good lecturers at ANU - who are they? And why would you say that they are so good? And (more important, perhaps?) what did you do this weekend? Was it good?

Good evening! mihi est dormiendum, as the Ancient Romans would say!

$\mathrm{W}$

Good afternoon, W!

You talk about Greek verbs - lucky you! "Eleipthen??"- it seems to me that you need a "lisp" to speak Ancient Greek (like with Spanish). I looked up the word for "lisp": the dictionary gives "lisca", but when I check the Italian side, as I usually do, "lisca" means "fishbone"! (Matthew, help me!)

Last Monday we stayed at our relatives, near Lake Illawarra on the coast. We enjoyed two clear days with stupendous views - a short but sweet break. You refer to the "weltwitschie" plant that lives in the desert. I think there are Australian frogs which hibernate for many years, until the rain (well, five years, not 500!) Have you studied botany? As for me, I've never studied science (except a bit of zoology at school). I'm ashamed - I know 
so un bel niente! Pero', forse potrei dire

che "nescire quaedam magna pars sapientiae est".

Di recente ho letto la biografia del fisico

Richard Feynman, "Genius" da James Gleick. I miei gusti sono vari!

Perche' direi che i professori sono bravi? Beh, loro ed io pensiamo allo stesso modo! Sto scherzando, un po', ma e' una domanda spinosa......

Le vacanze arrivano presto. Per te c'e' una pausa? Devo andare al lavoro tutti i giorni (sempre il mio lavoro include $l a$ fine-settimana).

A presto, $\mathrm{W}$

E

Ciao, E!

È spesso difficile conoscere la prononcia del greco dall'ortografia. Davvero il 'th' e il 'ph' greci sono come il ' $t$ ' e il 'p' inglesi ma non come il ' $t$ ' o il 'p' italiani, perché sono prononciati con l'aspirazione; dunque si non ha bisogno di balbettare per li prononciare!

La tua pausa al Lago Illawarra mi sembra molto buona e tranquilla. Vorrei che la mia fine-settimana fosse stata tanto tranquilla, ma era due giorni pieni di lavori - che peccato! Spero che le vacanze siano davvero tranquille, ma ho paura che la mia speranza non sia vero perché vado lavorare a

Sydney per quasi dieci giorni. Vado insegnare la matematica a una scuola delle vacanze per alcuni studenti intelligenti. Ti piace la matematica?

Non ho studiato la biologia o la zoologia, ma mi piacono i piantie gli animali. A Namibia non è difficile si interessare di biologia perché tutti gli animali e tutti i pianti sono tanto belli e tanto meravigliosi - davvero possono abitare in deserto! Allora, questo esercizio è molto divertente - ho imparato della biologia, di Peru, d'Iran, delle tante cose! Grazie per i tui email interessanti spero che potremmo ci parlare più nel futuro! A presto,

W

Both elaborate exchanges are between dyads consisting of an introductory level (A and $\mathrm{W}$ ) and a continuing level student ( $\mathrm{K}$ and $\mathrm{E}$ ). These exchanges are clearly qualitatively and quantitatively different to the pro forma exchanges. By contrast with exchanges 1 and 2 , these exchanges display the following traits:

- a broad range of topics - these are not limited to the immediate situation of the students (university studies, age, family, etc.) but significantly cover the students' interests and experiences

- evidence of linguistic risk-taking in the sense that students are experimenting with grammatical and lexical features which are outside their experience of formal instruction. Notably, in exchange 4, the more advanced student, in fact, highlights this in her metalinguistic comments on W's use of the imperfect

absolutely nothing! Anyway, maybe I could say

that "nescire quaedam magna pars sapientiae est".

Recently I read the biography of the physicist

Why would I say the lecturers are good? Well, they and I think in the same way! I'm joking,

a bit, but it's a thorny issue......

The holidays will arrive soon. Have you got a break? I have to work every day (my work always

See you soon, $\mathrm{W}$

Hi E!

It's often difficult to know the pronunciation of Greek from the spelling. The Greek 'th' and 'ph' are like English 't' and 'p' but not like Italian 't' or 'p', because they are pronou nced with stutter to pronounce them!

Your break at Lake Illawarra sounds very good and peaceful to me. I'd like my weekend to have been so peaceful, but it was two days full of work - what a shame! I hope the holidays are really peaceful, but I fear that my hope ' maths in a vacation school for some intelligent students. Do you like maths? I haven't studied biology or zoology, but I like plants and animals. In Namibia it's not animals and plants are so beautiful and so wonderful - they really can live in the desert! So, this exercise really is enjoyable - I've learnt about biology, about Peru, about Iran, about many things. Thanks for you interesting emails I hope we can talk more in the future! See you soon, $\mathrm{W}$ 
subjunctive. There are a number of examples of successful use of the present subjunctive and conditional

- a richer and broader lexicon than is found in the earlier pro forma exchange.

Also of note, in exchange 4 both participants comment positively on the email exchange exercise which we take as clear evidence of a heightened engagement with the exercise. Given the breadth of topic and range of grammatical features in the elaborate exchange, we can confidently assert that these students did indeed take advantage of the asynchronous environment to produce messages of considerable quality. These exchanges are also much more dialogic in nature than the earlier pro forma examples. These examples demonstrate that a relationship does indeed exist between the linguistic form and content of the communicative act.

It can also be claimed that the linguistic and content-related aspects of the emails examined reflect the individual characteristics of each student: their level of motivation, their personal approach to the task of communicating via email in Italian and their experiences as language learners.

We would claim that the more successful interaction found in the elaborate exchanges is a result of the electronic environment which provides students with a supported context for language use that favours risk-taking. Exchange 4, in our view, illustrates that when students are exposed to such an environment their natural disposition as autonomous learners is allowed to come to the fore (Trevitt, p.c).

\section{PEDAGOGICAL IMPLICATIONS}

The present study suggests not only that email communication provides students with the chance to communicate in the target language in a communicatively authentic context, but also that the electronic environment itself influences the way in which the language is presented and the shape the langua ge takes. In summary, we have noted that using electronic mail in a language course encourages the most reticent students to participate and, due to the freedom from constraints of space and time, allows learners to construct messages which communicate ideas with success. It is particularly valuable to reflect on whether these characteristics might have a positive flow-on effect to oral production. Baron (1984) holds that electronic communication does influence spoken language and that it is reasonable to expect an improvement in the levels of logical and grammatical cohesion of spoken discourse. Roed suggests that the "virtual environment can work as scaffolding: gradually giving anxious students more confidence to embark on conversation in the target language" (Roed, 2003, p. 170). With regard to foreign languages, it is important to recall that the written and spoken abilities of the learner do not develop in a uniform fashion and that therefore the impact of electronic communication can manifest itself differently: on the one hand, spoken language can be influenced positively by an overall increase in logical coherence and grammatical accuracy owing to the written nature of electronic communication; on the other, written language can benefit from the immediacy and spontaneity of oral modes. Stockwell \& Levy (2003) describe factors which lead to sustainability of email interaction between NS and NNS. Their study usefully identifies a taxonomy of online profiles (ie. types of leaners) (Stockwell \& Levy, 2003, p. 431-433) and categorises dyad dynamics (Stockwell \& Levy, 2003, p. 433-435). The range of profiles includes

- the low-motivation student

- the daunted student 
- the struggling student

- the technophobic student

- the inconsistent or slow reponder

- the ideal high performer

The authors describe five sets of dyad dynamics:

- dyads with nothing in common

- the mismatched dyad

- 'let's stick to the topics' dyads

- dyads with lots in common

- developing friendships

Stockwell \& Levy (2003, p. 436-7) conclude that two factors impact on sustainability: higher language proficiency and a willingness on the part of dyads to venture beyond assigned topics into their own areas of interest.

While our study did not focus on sustainability, we can draw parallels with Stockwell \& Levy in terms of quality of exchanges. Because our study dealt with NNS-NNS exchanges the range of online profiles is reduced and we would suggest configuring the taxonomy as a continuum based on motivation with the low-motivation student at one extreme and the ideal high performer at the other. In this way, we would link the type of exchange to an online profile: low-motivation students were more likely to produce pro forma exchanges while elaborate exchanges would correlate with ideal high performers. Similarly, in relation to dyad dynamics, the 'let's stick to the topics' dyads were more likely to produce pro forma exchanges while the developing friendships dyads produced elaborate exchanges.

A factor which emerged as critical for quality exchanges was the age, or perhaps life experience, of the student. In all cases, mature aged students contributed more and of better quality than their younger counterparts. This is perhaps unique to our cohort of students and would need to be examined on a larger scale. These claims can be supported empirically. A statistical analysis of the word length of the initial introductory emails revealed that, for our cohort, increasing age correlated with increased length of the email message (see statistical analysis in appendix 1). Similarly, analysing the exchanges above using the Gulpease index of legibility (http://www.eulogos.net/it/censor/) reveals that the elaborate exchanges are slightly more complex. Texts are scored on a decreasing scale of complexity, ie the lower the score, the more complex the text On the Gulpease scale, exchange 2 scores 118 which indicates that it is very easy to read. Exchange 4 scores 96. This is still in the very easy range but is more complex than the pro forma exchange 2 . A second factor which is in full agreement with Stockwell \& Levy's findings relates to topic. In the distinction between pro forma and elaborate exchanges which we drew above the salient difference is the range of topics. Just as venturing into wider topic areas promoted sustainability of email dialogue in Stockwell\& Levy's study, so a similar situation led to exchanges of higher quality in the present study. The pedagogical implications of this situation seem fairly self-evident, namely, that the sustainability and quality in CMC depends crucially on constructing exercises which allow students to pursue their own topics of interest.

\section{CONCLUSIONS}

Analysing the data collected, allows us to outline a series of characteristics relating to the language students produced in the electronic context. These aspects include: 
- a generally more spontaneous and natural style compared to other written texts

- an individual and expressive language both in terms of content and typographic elements

- greater expressive freedom with respect both to traditional written forms and oral discourse.

The integration of email as a support to other teaching and learning activities represents without doubt significant added value both for learners and instructors in terms of

- motivation

- participation rate

- development of linguistic abilities

- communication in an authentic context

- getting to know fellow learners

- development of skills which will be easily transferable to contexts other than university.

The aim of the present study was to offer a reflection on the specific traits of electronic communication in the context of foreign language learning in order to stimulate a discussion of its pedagogical implications and of learner behaviour online. Future studies in this area are required to fully appreciate the strategies and mechanisms which students use to effectively communicate in new electronic contexts. This is turn will lead to a greater understanding of how to best integrate the use of technology into the teaching and learning of languages.

\section{ACKNOWLEDGEMENTS}

The authors would like to thank Penny Collings, Chris Trevitt and Lesley Shield for their critical insights on earlier drafts of this paper. We are indebted to Bruce Brown for his statistical expertise.

\section{REFERENCES}

Baron, N.S. (1984). Computer Mediated Communication as a Force in Language Change. Visible Language, 18(2), 118-141.

Baron, N.S. (1998). Letters by phone or speech by other means: the linguistic of email. Language \& Communication18, 133-170.

Beavois, M.H. \& Eledge, J. (1995). E-talk: Attitudes and motivation on computerassisted classroom discussion. Computers in the Humanities. 28, 177-190.

Bertocchi, D. (1999). L'e-mail si scrive o si parla? Italiano e oltre 14, 70-75.

Chapelle, C.A. (2001). Computer Applications in Second language Acquisition. Cambridge: Cambridge University Press.

Fedderholt , K. (2001). An email exchange project between non-native speakers of English. ELT Journal, 55(3), 273-280.

Gonzales-Bueno, M. (1998). The effects of Electronic Mail on Spanish L2 Discourse Language Learning and Technology, 1(2), 55-70.

Kitade, K. (2000). L2 Learners' Discourse and SLA Theories in CMC: Collaborative Interaction in Internet Chat. Computer Assisted Language Learning, 13(2), 143166.

Lapp, S.I. (2000). Using Email Dialogue to Generate Communication in English as a Second Language Classroom. The Australian Journal of Language and Literacy, 23(1), 50-61. 
Leahy, C. (2001). Bilingual Negotiation via E-mail: An International Project. Computer Assisted Language Learning, 14(1), 15-42.

Maynor, N. (1994). The language of electronic mail: Written speech?, In G. Little \& M. Montgomery (Ed.), Centennial usage studies. American Dialect Society, 78, 4854.

Porcelli, G. \& Dolci, R. (1999). Multimedialità e insegnamenti linguistici. Modelli informatici per la scuola. Turin: Utet.

Ramsden, P. (1992). Learning to Teach in Higher Education. London: Routledge.

Richards, J.C. \& Rodgers, T.S. (1986). Approaches and Methods in Language Teaching. Cambridge: Cambridge University Press.

Roed, J. (2003). Language Learner Behaviour in a Virtual Environment. Computer Assisted Language Learning, 16(2-3), 155-172.

Spina, S. (1998). L'uso di internet nella didattica delle lingue straniere: problemi e prospettive. (http://www.cilea.it/collabora/GARR-NIR/nir-it98/atti/spina.pdf)

Sproull, L. \& Kiesler, S. (1991). Connections: New Ways of Working in the Networked Organization. Cambridge, Massachusetts: The MIT Press.

Stockwell, G. \& Levy, M. (2003). Sustainability of E-mail Interactions Between Native Speakers and Nonnative Speakers. Computer Assisted Language Learning, 14(5), 419-442.

Warschauer, M. (1995). Virtual Connections: Online activities and projects for networking language learners. Honolulu: University of Hawai'i, Second Language Teaching \& Curriculum Center.

Warschauer, M. (1996).Motivational aspects of using computers for writing and communication. In M. Warschauer (ed.).Telecollaboration in foreign language learning: Proceedings of the Hawai'I Symposium. Honolulu: University of Hawai'i, Second Language Teaching \& Curriculum Center.

Warschauer, M. (1997). Computer mediated collaborative learning. Theory and practice. The Modern Language Journal, 81, 470-481.

Warschauer, M. (1999). Electronic Literacies. London: Lawrence Erlbaum Associate Publishers.

Warschauer, M. \& Kern, R. (2000). Network-based Language Teaching: Concept and Practice. Cambridge: Cambridge University Press.

Weininger, M.J. \& Shield, L. (forthcoming). Promoting oral production in a written channel: an investigation of learner language in MOO. 
Appendix 1: Statistical analysis of word length of introductory emails compared with age of students

This analysis was conducted by Associate Professor Bruce Brown, Statistical Consulting and Research Centre, University of South Australia.

\section{Kendall's tau and the association between age and word count.}

Kendall's $\tau$ is a nonparametric measure of association which has better mathematical properties, but is more difficult to compute, than the more widely used Spearman's $\rho$. In particular, Kendall's $\tau$ has an easy modification to handle ties in one variable.

Let $\left\{\left(x_{i}, y_{i}\right), i=1, \ldots, n\right\}$ be a set of independently observed pairs. In the present case $x_{i}$ is the age in years and $y_{i}$ is the word count of the $i$ th subject. Kendall's $\tau$ measures the extent to which $x, y$ tend to increase or decrease together, giving it a natural, meaningful interpretation. The definition is:

concordance measure $T=\sum_{i<j} \operatorname{sgn}\left\{\left(x_{i}-x_{j}\right)\left(y_{i}-y_{j}\right)\right\}$, and

$$
\tau=\frac{2 T}{n(n-1)}
$$

Thus $-1 \leq \tau \leq+1$, with $\tau=+1$ if $x, y$ are in exactly the same order, and $\tau=-1$ if $x, y$ are in exact reverse order.

Under the null hypothesis $H_{0}$ : the $x, y$ variables are independent (ie have no association), the concordance measure $T$ has an approximate normal distribution with mean zero and variance

$$
\sigma_{n}^{2}=\frac{n(n-1)(2 n+5)}{18}
$$

When there are ties in the $x$ variable, there are unobservable contributions to $T$ from within every tied group, and the variance of what those independent contributions would have been (if the ties were broken) has to be subtracted from $\sigma_{n}^{2}$. Then,

$$
\operatorname{var}(T)=\sigma_{n}^{2}-\sum_{i} \sigma_{k_{i}}^{2} \text {, where the sizes of the tied groups are }\left\{k_{1}, k_{2}, \ldots\right\} .
$$

In the present example of age and word count, we have $n=66, T=357$ and the sizes of the tied groups are as follows.

\begin{tabular}{|l|l|l|l|}
\hline multiplicity & $k_{i}$ & ages & $18 \sigma_{k_{i}}^{2}$ \\
\hline
\end{tabular}




\begin{tabular}{|c|c|c|c|}
\hline 1 & 17 & 18 & 10608 \\
\hline 2 & 12 & $19,30+$ & 3828 \\
\hline 2 & 6 & 20,22 & 510 \\
\hline 1 & 4 & 17 & 156 \\
\hline 1 & 3 & 21 & 66 \\
\hline 2 & 2 & 23,24 & 18 \\
\hline
\end{tabular}

Thus, and with $n=66$, we have $\sigma_{n}^{2}=32651.667$, giving

$$
\begin{aligned}
\operatorname{var}(T) & =32651.667-1085.667 \\
& =31566=177.67^{2} .
\end{aligned}
$$

For a two-sided test of $H_{0}$, the P-value is

$$
\begin{aligned}
P & =\operatorname{Pr}(|T| \geq 356.5) \text { (using a continuity correction) } \\
& =2 \operatorname{Pr}(T \geq 356.5) \\
& =2 \operatorname{Pr}\left\{Z \geq \frac{356.5}{177.67}\right\}=2 \operatorname{Pr}(Z \geq 2.01)=0.044
\end{aligned}
$$

from standard normal Tables.

This is significant, and the conclusion is that there is evidence suggesting that word count tends to increase with age.

\footnotetext{
${ }^{\mathrm{i}}$ To protect the privacy of the individual students, we have reduced all names to initials only.
} 


\section{University Library}

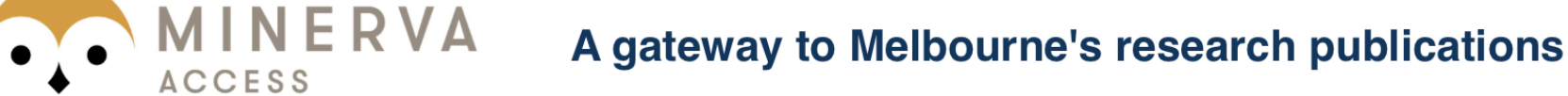

Minerva Access is the Institutional Repository of The University of Melbourne

Author/s:

ABSALOM, MATTHEW;Pais Marden, Mariolina

Title:

Email communication and language learning at university - an Australian case study

Date:

2004

Citation:

Absalom, M., \& Pais Marden, M. (2004) Email communication and language learning at university - an Australian case study. Computer Assisted Language Learning, 17(3-4), 403-440.

Publication Status:

Published

Persistent Link:

http://hdl.handle.net/11343/34510 